\title{
LIVES BROADCAST (360 4K AND 8K) ON SOCIAL MEDIA - SAVING ON SEO, ADS AND RESOURCES (DEMO LIVE 360 4K)
}

Chair: Rodrigo Dias Arnaut - Director - EraTransmidia/ FAAP/ SET/ Esconderijo Multidisciplinary experts present their different visions, solutions, cases and experiences in the field of live streaming of social media video (known as lives on the web), using new technologies that include 360-degree imaging and connectivity anywhere, bringing remote immersion From the viewer to the actual scene, with quality standards at $4 \mathrm{~K}$ and up to $8 \mathrm{~K}$. The use of lives on the web is increasingly popular, given the ease of the tool and the low cost of resources. For example, a \$170.00 VR camera such as Insta360 Air, a \$ 250.00 smartphone and a low-cost $4 \mathrm{G}$ or satellite internet plan, which is increasingly accessible, make anyone into a UMPP (Personal Portable Mobile Unit), ready to enter live from anywhere, anytime. Come to understand this new world of lives and discuss with the experts, and in the end, we will have a round of questions and answers, plus a demonstration with a 360 lives solution, 4K satellite!

- LIVES VIA SATÉLITE Speaker: George Bem - CEO \& Founder - InternetSAT

This talk will present live streaming cases (PetChannel and Canal Rural) with details of the optimized infrastructure and cost reduction achieved in the projects. It will also announce the launch of a new satellite in KA band, with start of operation in October 2017, for live streaming.

- SOCIAL MEDIA AND THE WORLD OF LIVES Speaker: Juliano Kimura - CEO \& Founder - Trianos

Why using lives in social media can bring a more positive result than simply sponsoring online campaigns. How video content engenders greater engagement and reach of fans, and how using technology in a simpler way can generate profit and savings for businesses.

- LIVES AND GAMES 360

Speaker: Pedro Zambarda - CEO \& Founder Drops de Jogos, editor-chefe Mundo360 
Will present the global scenario of lives 360, immersive content, technology events such as E3, 360 in social media and the transmission of games over the Internet.

\section{- 360 CAMERA SOLUTIONS}

\section{Speaker: Juliano Milanez - Manager - SHVAV / Pixellot / Rohde-Schwarz}

Will present an overview of the current 360 cameras and will show a broadcast solution to transmit images to 360 Virtual Reality with $8 \mathrm{~K}$ quality for applications in sports and entertainment.

\section{- 360 TRANSMISSIONS, FROM THE PLAYER TO THE GLASSES}

\section{Speaker: Charles Boggiss - CEO - UView360}

With more than 10 years of experience in imaging and broadcasting 360, we will present discoveries and cases that show that virtual reality technology is increasingly accessible.

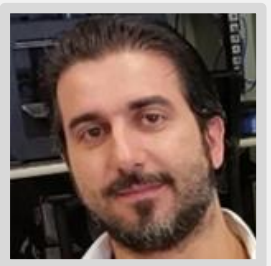

\section{Rodrigo Dias Arnaut - Director - EraTransmidia/ FAAPI SET/ Esconderijo}

ransmedia consultant and planner for producers and agencies, by Esconderijo das Crianças, digital media professor at FAAP in communications courses, undergraduation and pos graduation. Master of Science from USP (Poli), specialization on Business Management and Technological Innovation at ESPM, Computer Engineer at USJT. Concluded an extension course in E-business in UofT (University of Toronto). President at EraTransmidia Association, where he currently develops audiovisual production research in the field of immersive video, virtual reality / augmented and actions of social impact. With 25 years of professional and academic experience in Technology, Business and Communication in brainstorming and Transmedia projects, IT, Telecom, TV, IoT, Mobile, Web, Games, Wearables, Interactivity, Holography, Virtual and Augmented Reality, Media Advertising and marketing, 21 years in the Globo group at R\&D Research and Development for technology to Sports areas, Journalism and Entertainment, where he developed more than 50 projects received 15 awards, highlighting IBC Special Awards of the "float" (Amsterdam). It is also a partner at startup Gigamobb and consulting at Esconderijo das Criancas, focused on developing projects with MAMP methodology (Multi Platform Multi Audience) created by EraTransmídia. Vice Director of Pay TV and New Media at SET. Speaker at over 200 events in Brazil and abroad.

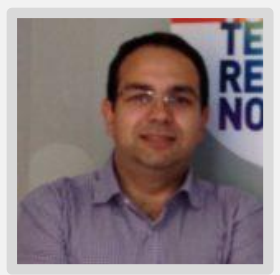

\section{George Bem - CEO \& Founder - InternetSAT}

CEO and Founder of InternetSAT, graduated in Telecom Eng. By Fasp, Postgraduate in Critical Mission Environments and Projects. Acting in the telecom area, through IT, Internet and Broadcast. Responsible for the startup of R7.com, he acted as Mang. And Serv. Of Eng Record, responsible for new IP technologies, data networks and videos and mobile. 

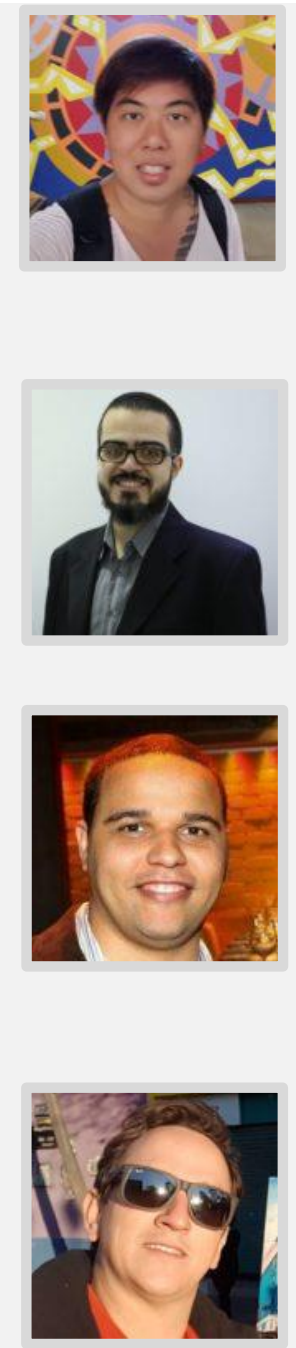

\section{Juliano Kimura - CEO \& Founder - Trianos}

One of the most influential professionals in the world of social networks and digital innovation. He has 15 years of experience in the digital communication market. Was a speaker and content expert for Facebook Brazil. Managing Partner of Trianons Academy and creator of Social Brunch and Tampopus.com projects. Elected best social networking professional by ABComm in 2015 and 2016. His company was voted best social networking agency by the E-Awards.

Pedro Zambarda - CEO \& Founder Drops de Jogos, editor-chefe Mundo360 Journalist, writer and communicator. Graduated in Journalism from Faculdade Cásper Líbero and in Philosophy at FFLCH-USP. He is the editor-in-chief of Games Drops and editor of the Generation Gamer project. He writes about games, technology, politics, business, economics, and society.

\section{Juliano Milanez - Gerente - SHVAV / Pixellot / Rohde-Schwarz}

Experienced as country Manager with a demonstrated history of working in the broadcast media industry. Skilled in Non-linear Editing, Broadcast Engineering, Radio, Management, and Sound. Strong community and social services professional with a IT Management, Specialized in Virtual Sets, video servers and augmented reality systems, great skills with MAM, PAM and project management.

\section{Charles Boggiss - CEO - UView360}

